\title{
TECHNOLOGY ADOPTION IN DIFFUSION OF INNOVATIONS PERSPECTIVE: INTRODUCTION OF AN ERP SYSTEM IN A NON-PROFIT ORGANIZATION
}

\author{
Marília Queiroz Miranda \\ Bacharel em Administração pela Universidade de Brasília - UNB \\ marilia_mirandaa@hotmail.com (Brasil) \\ Josivania Silva Farias \\ Doutor em Administração pela Universidade de Brasília - UNB \\ Professor da Universidade de Brasília - UNB \\ josivania@unb.br (Brasil)

\section{Carolina de Araújo Schwartz} \\ Graduanda em Administração da Universidade de Brasília - UNB \\ carolschwartz21@gmail.com (Brasil)

\section{Juliana Pascualote Lemos de Almeida} \\ Mestranda em Administração da Universidade de Brasília - UNB \\ juliana.pascualote@gmail.com (Brasil)
}

\begin{abstract}
This study aimed to describe the adoption process in light of the diffusion of innovations and technologies of the management system Enterprise Resource Planning (ERP) in a non-profit organization, considering inhibiting and facilitating factors of this process and innovations or arising benefits. A descriptive qualitative approach was conducted through a Case Study. Triangulation of researchers was used in the content analysis of the empirical evidences obtained through 17 structured interviews. It was concluded with this study that the facilitating factors outweigh the inhibiting factors of the adoption of the system. With regard to innovations arising from the adoption of this technology, it was found that there were process and administrative innovations through the implementation of new processes, practices and structural organization, which resulted in the effective reach of the organization's objective, with respect to the compliance for business customers which had as goal to adjust themselves to the standards of minimum quotas for hiring young apprentices.
\end{abstract}

Keywords: Technology Adoption; IT; Innovation. 


\section{INTRODUCTION}

The adoption of a new technology, which can result in innovation, is justified by the goal of "changing the organization's status quo in search of improvements" translated in offering a product or service satisfactory to the customer (Dias, 2000, p. 52).

Seeking improvements in order to remain competitive in the market, Organizations today have have found in the reorganization of its processes an alternative to meet cost-cutting requirements and improvement of its internal resources. Thus, the information system through information technology (IT) is an aid in the search for solutions and to identify opportunities for innovation and development (Mussi \& Canuto, 2008).

In this regard, Farias, Guimarães and Vargas (2012, p. 27) state that "innovation in organizations usually involves changes in the culture and organizational behavior, resulting in change." However, the change may not be committed to adopting new technologies and innovations do not take into account the essential steps to effect this process. The diffusion process of technologies and innovations is complex and, according to Rogers (1983), follows a set of stages that will be discussed in this paper. The conceptual framework for the decision-making process of innovations proposed by Rogers (1983) was adopted because this theoretical framework can also be used in the study of how individuals, groups or organizations adopt and diffuse technologies that can result in the proliferation of innovations in the case of be achieved demonstrable benefits. The new technologies have caused significant changes in the organizational production (Motta, 2001) and those changes can be in episodic or continuous order, thus creating conditions for the occurrence of innovations (Weick \& Quinn, 1999).

Venkantesh et al. (2003) indicated the need for further research focusing the process by which individuals adopt technologies and the factors influencing its use, as well as in understanding of the degree to which information systems (IS) and information technology (IT) are perceived as successful (such as ERP) for organizations, in the adoption of technologies perspective.

This study may contribute to the extension of knowledge about the adoption of information systems and technologies (IT) applied to the management of nonprofit organizations, proposing the improvement of the service offered to society. Often organizations have neglected the generation of learning and innovation, do not taking into account that these two capabilities can be fundamental in the search actions for sustainability in the market (Mendonça \& Araújo, 2005).

Revista de Administração e Inovação, São Paulo, v. 13, n.1, p. 103-123, jan./mar. 2016. 
Considering the above-mentioned issues, this study aimed to describe, in view of the diffusion of innovations and technologies, the adoption process of an Enterprise Resource Planning (ERP) a management system in a non-profit organization, considering hindering factors and facilitators of this process and possible innovations or gains.

\section{THEORITICAL APPROACH}

Technology is a "potentiator source of possibilities and options" (Kelly, 2012, p. 42), allowing savings of time and costs to organizations. Its technique nature and method are closely associated to knowledge that when applied to practice can provide competitive advantage for companies in the economic scenario.

Zawislak (1994, p. 3) addresses the technology through knowledge, that is, of "new ideas, new appliances, new methods, new techniques and new technologies" that influence and generate development. Knowledge is linked to the nature of technology, and can be respected by techne and episteme, being the techne the know-how, i.e. an implicit knowledge for the practice (savoir-faire) about something and episteme the universal, analytical, cerebral knowledge, based on theory, impersonal, i.e., that is Scientific. So it has technology as the techne that is associated with the logos, aiming the logical analysis of phenomena.

Technology can initiate the development and, therefore, organizations adopt new technologies aiming to improve internal processes and, thus, to offer better services and products to the market, remaining themselves competitive (Zawislak, 1994). It is in this perspective that it is presented the information technology (IT), one of the elements related to the Information Systems (IS) (Laudon \& Laudon, 2007; O'Brien, 2004).

The Enterprise Resource Planning (ERP), technology addressed in this research, is a tool which uses modular software packages (or applications) connected to a common central database that allows the integration of the organization in its different business stages (Moura, 2006). Thus, provides information on the production process, allowing decision-making at various levels in an appropriate way and in perfect time, from information integrated into a single database. Once there is consistency in the data, it is possible to make comparisons, to avoid repetition, redundancy and bureaucracy in the 
use of information for decision support. This paper proposes that all these benefits can contribute to changes and even innovations.

Technological innovation is the main engine of economic development (Arthur, 2011). At the organizational level, it is one of the bases used to adapt to the rhythm of the market dictated by globalization (Mussi \& Canuto, 2008). According to Stal (2007), innovation is the development of a new method, device or machine that, on the market, could change the way in which things happen. This change has to be transformative in bringing improvements (Tigre, 2006). According to the Oslo Manual (OECD, 2010, p. 12), "innovation is clearly part of a business strategy based on transforming ideas into value. Generally, improved goods, services or processes" and can be configured as product, process, marketing and organizational innovation.

Regarding the nature of change, Weick and Quinn (1999) distinguish this in: continuous change (tends to be cumulative, continuous, engaging and emerging, which occurs in day-to-day through upgrades of production processes and social practices) or episodic change (tends to be abrupt, infrequent, discontinuous and intentional, caused by an external factor when organizations face periods of differences and changes from its equilibrium condition). Both create conditions for innovations. Thus, the adoption of IT can promote changes in strategy, culture, processes and structure (Graeml, 2000) which may lead to organizational innovation.

Innovation studies can hardly do without concerns about the spread. This paper argues that, from a theoretical point of view, also in studies on adoption of technologies there is a process or set of stages that establish different schemes relating to chained decisions that can make the technology adopted achieves confirmation (Rogers, 1983), thus contributing to innovation.

Cooper (1990) proposed the Stage-Gate model that shows the process by which a product is designed and have to add to the study of innovation and diffusion of technologies. The model has five phases and five decision points which define the continuity or discontinuity of an innovation project, namely: 1) preliminary investigation to probe the viability of the project;2) further investigation; 3) product development; 4) testing for validation and 5) release of the product on the market (Cooper, 2000).

Tornatzky and Fleischer (1990) discuss the technological innovation process from different perspectives, namely: the user's perspective (people), the Working Group, the firm or the environment. Thus divided into two main segments, it has been the developer's perspective and user's perspective. Some steps inherent in almost all perspectives and stakeholders are aware of the problems, selection of corresponding standards, and commitment to the adoption, implementation and routinization. There 
are different elements involved in this process, such as various activities and events, individual decisions and behaviors. This model features from the early stages of developing a new technology to effective use, considering several rounds of feedback, making iterative process.

Rogers (1983) proposed the Innovation Diffusion Theory (TDI), consisting of five stages, which occur over time, given the influence of the social system and the communication channels.

The Innovation Decision Process is the search for information made by a sequential activity in which the subject is motivated to reduce uncertainty about the advantages and disadvantages of a particular innovation. This process consists of five phases, as evidenced in Figure 1, namely: previous conditions for adoption, knowledge about innovation or technology, persuasion of the possible adopter by deepening the knowledge about technology and searching for more information about the same; decision to adopt or reject the technology; implementation, that is the moment in which the technology is put into use; and finally the stage of confirmation in which the adopter evaluates and decides the maintenance of the adoption or rejection of it after it has been put into use.

Figure 1. Decision Process Innovation (ROGERS, 1983, p. 165)

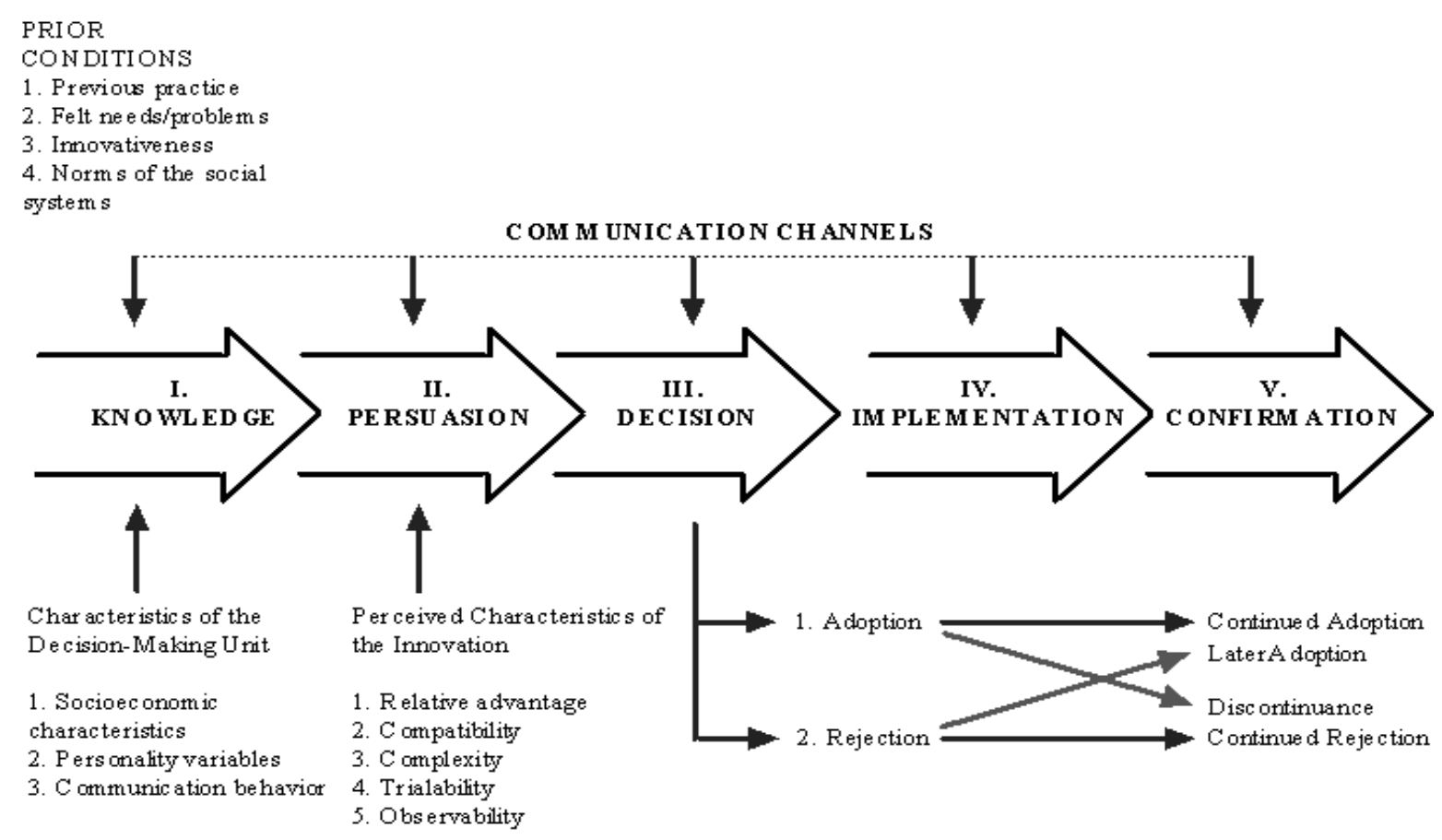


This study focused on this model of Rogers (1983) to structure and report the decision making process for adoption of ERP technology in the organization studied.

\section{METHOD}

The research was conducted in a Brazilian nonprofit organization that serves individuals in socially vulnerable. In June 2014, the organization has implemented an Enterprise Resource Planning system (ERP). This decision is linked to the nature of the programs and projects undertaken by the organization, especially the Jovem Aprendiz Brazilian Program, in parameters of the Decree No. 5598, December $1^{\text {st }}$, 2005, that offers vocational courses in theoretical module (vocational courses) and practical (apprentice working in partner companies) to more than 2,100 young people in the Federal District (DF) of Brazil.

This organization won a bidding process, along with other organization of the same area of expertise, thus leading to a significant increase in hiring apprentices. Thus, a need arose for implement an automated system that manage the administrative and financial processes involving all internal employees of the organization simultaneously to the management of all learners. This organization has hired 116 employees and 133 volunteers allocated to various programs and projects carried out by it.

The subjects of this research correspond to 17 employees of the administrative and financial area, and the Chief Executive Officer of the organization and the people involved with the use of the ERP system, considering the Personnel Department RM Labore module. To this end, we developed a case study of qualitative and descriptive approach.

The collection of empirical evidence occurred in October 2014, through interviews with structured scripts - one for the interview with the director and the other two interviews with managers and administrative assistants - direct and indirect users of the technology adopted.

The content analysis of empirical evidence was made by means of categorizing a priori, i.e., prior establishment of eight core classes defined from Rogers (1983) and other categories already cataloged in the literature by Farias and Almeida (2014). Besides the a priori categorization, if adopted, also categorization retrospectively order to identify new categories raised in the statements, but not covered in Rogers (1983).

Considering what recommends Guion (2002) that to improve the validity and reliability of qualitative research, triangulation can be a way out once again, that the greater the convergence of views, more validity and quality can get the result of the study, it was conducted a content analysis by 
triangulation of researchers (Paulien, 2002), consisting of the joint evaluation by researchers in the same field of knowledge, seeking convergence of views. Thus, the content analysis was conducted by four researchers, and the education level of each researcher: doctoral, master's in progress and two researchers with a degree in progress, a research group of participants linked to an Administration graduate program in a Brazilian federal university, through three rounds of meetings held in November 2014 and the exchange of several emails aimed at validation by identifying the differences and similarities in relation to the categorization.

During the meetings, in order to identify specific categories or not bounded by Rogers (1983) or by Farias and Almeida (2014) in the corpus of the corresponding texts to the interviewees' statements, - these two authors have cataloged 50 intervening factors for technology adoption in organizations, which facilitated a priori categories of classification, thus speeding up the process of analyzing content and triangulation. When it was located some convergence with the literature in the statements of those interviewed, the researchers analyzed whether this category had been raised in a previous study. When there was disagreement or doubt regarding any concept or category, it was discussed the issue in order to reach the convergence of researchers (waiting at least $80 \%$ agreement) as to the appropriate categorization.

\section{ANALYSIS OF RESULTS}

This section presents and discusses the results found in this study.

It should be clarified that the subjects were targeted from the level of decision and participate in the organization in order to perform more detailed analysis of the results from the role of each participant in the process. They established the strategic level (CEO), tactical (coordinators) and operational (analysts, assistants and assistants). Table 1 presents the acronyms and their subjects: 
Table 1: Acronyms adopted in accordance with the subjects

\begin{tabular}{c|c|c|c}
\hline INITIALS & ROLE & INITIALS & ROLE \\
\hline DP (strategic) & President Director & ASDP1 (operational) & Personal department assistant \\
\hline CA1 (tactical) & Administrative coordinator & AA2 (operational) & Administrative assistant \\
\hline CDP (tactical) & $\begin{array}{c}\text { Personnel Department } \\
\text { coordinator }\end{array}$ & AA3 (operational) & Administrative assistant \\
\hline P (tactical) & Psychologist & ANDP1 (operational) & Personal department analyst \\
\hline AS (tactical) & Social Worker & AA3 (operational) & Administrative assistant \\
\hline CP (tactical) & Educational coordinator & ASDP2 (operational) & Personal department assistant \\
\hline AAC (tactical) & $\begin{array}{c}\text { Administrative Analyst } \\
\text { Commercial }\end{array}$ & ANDP2 (operational) & Personal department analyst \\
\hline CA2 (tactical) & Administrative coordinator & AA4 (operational) & Administrative assistant \\
\hline AA1 (operational) & Administrative assistant & & \\
\hline
\end{tabular}

It is worth mentioning that at present the results in subsections 4.1 to 4.7 it will be considered the same logic of the stages of Rogers (1983).

\subsection{The prior conditions for the adoption of the technology}

The first stage of the decision-making process of innovation (Rogers, 1983) is called the step previous conditions and refers to the situation where the organization formerly in the adoption of innovation or technology. In this stage, there are previous practices, perceived needs and problems, the degree of innovativeness (innovativeness) of the decision unit and the established social norms. It showed up in the collection of empirical evidence that 7 from the 17 respondents were not working in the organization during this step.

Prior to the adoption of the ERP system, the organization used various tools; there is no standard between what should be adopted in all departments. The most commonly used tools were the spreadsheets, shared through email and web. There were activities carried out manually, which raised the amount of paper, then the effort to scan some documents without significant success. In this regard, the AS interviewed (tactical) said:

\footnotetext{
"Everything done on paper, we had folders, files and everything was in folders, all of the research that we needed, we had to resort to the folders to be able to have that information one by one. We tried to put some spreadsheet on the computer, but that was just not working right."
}

Beyond these tools it was used an integrated system widespread in small and medium-sized companies that had better performance in the accounting module at the expense of the HR module. The software does not significantly contributed to the integration between modules and degree of complexity to perform some activities, as described by the CDP interviewed (tactical): 
"First, it was a software that was :: (...) a 'software' very good, but very closed. For example, there was difficulty on some issues such as reporting and other things that would have to meet the need of the 'institution'. "

Because of the degree of complexity of the software and the lack of specialized professionals in the HR field with knowledge of even complex tasks such as those related to the Personnel Department, they were carried out by an external company that used the same software adopted by the organization. This entailed in immobilization processes and more time and effort to the closing payrolls. Thus, the three main needs described by the interviewees are related to agility, control and integration of the information system for decision support.

Then, it was mentioned the need for control and integration of information systems for decision support. Regarding the perceived need of control, it was reported that there was loss of data and information, lack of information and errors. The testimony of the respondent CA1 (tactical) demonstrates the lack of existing control:

"The trouble is... the information, it was too much information to spend, too much information to arrive and it was something to back, for example, is spent... termination of the term of payment, vacation that should be 'paid' two days earlier, then paid later because it had no control of who had to go on vacation, from who... from who was with the contract to expire."

Farias, Guimarães and Vargas (2012, p 35) indicate that the control can manifest itself in different forms, namely:

"1) Control time, streamlining the assistance; 2) control of work, changing working methods and behaviors, as well as providing performance monitoring of people and sectors; 3) cost control and 4) control of information with regard to safety, registration and storage, providing intelligent systems for decision support. "

So in the reports, there was a high incidence of need for information control.

Another item often cited was the system integration, which is seen as the need for database powered single base, which distributes the information to all sectors. AS interviewed, (tactical) said:

"(...) It was used web, but it was not a system, 'right'. Then if you make some change, not everyone has access to that change, It is not recorded in the system." 
Besides the three perceived needs were also cited: tool compatibility requirements to the organization's needs; a tool that would meet the increased volume of services; automation; administrative organization and work; information for decision support; constantly updated tool of information; reliable information; and improved quality of service.

As mentioned in section 3 of this Article, by increasing the number of apprentices to be met, it became necessary to purchase a system that would make it agile and easy to carry out administrative and financial tasks. This resulted in hiring specialized labor, work and deep knowledge of the Personnel Department area. When referring to software previously adopted, the CDP interviewed (tactical) reported:

"The tool was very good, but for a company of a smaller size. Being that arose larger projects, this technology would not be satisfactory for the "institution" but, while it was used, it was very helpful. "

Considering the discussion of innovativeness made by Rogers (1983), defined as the degree to which a unit of decision anticipates the adoption of new ideas in relation to other members of a system, it could be shown that the organization does not seem to fit into this profile, as it does not anticipate the adoption of new technologies, but showed reactive posture as it needed the technology because of the sudden increase in demand for services. The subject CA2 (tactical) could perceive this:

"(...) Here, it was the only place I worked that did not have (a software). All companies in 'what' I worked, I have worked since 1996, all the companies I've worked already 'had' software. Then the management of all sectors, as well, it was not only a module of such department, it was a complete management software, you knowt? (...)".

\subsection{The knowledge stage of the adopted technology}

This section aims to describe how the knowledge stage about the existence of the system and its operation occurred. According to Rogers (1983, p. 165), "the knowledge stage occurs when an individual (or other decision unit) is exposed to the existence of innovation and gains some understanding of how it works."

Being asked about previous experience with similar or equal systems or software, 9 from 17 subjects reported that they had had prior contact 7 from 17 reported that they did not have any experience. Only one subject of the tactical level hired after the adoption of the system, shown to have full knowledge about its functioning, having used several other such systems, having worked on the organization of the system developer and participated in more than 60 training. The number of staff

Revista de Administração e Inovação, São Paulo, v. 13, n.1, p. 103-123, jan./mar. 2016. 
with little previous knowledge of the tool affect the Innovation Decision Process (Rogers, 1983). In case of more complex innovations, it is necessary even greater degree of knowledge, and when there is no adequate level of knowledge, there is a greater propensity for rejection or discontinuation. Often decision-makers are not the implementers (Rogers, 1983). In this organization, subject only to the strategic and tactical management level know how to answer how was the knowledge of the organization of the existence of the system and its operation, reporting that this was done through the presentation of the system or by a partner organization operating in the same sector and branch.

The knowledge of the system operation by some operational level of the individual occurred after the adoption, at the stage of implementation and confirmation, which shows that the organization "burned" steps. The consequence of this became evident in later stages as the individuals reported problems such as the need to adapt the system to not make mistakes and lack of knowledge about the tool. They were also reported as forms of knowledge of system operation, some internal training, taught by the subject with greater knowledge, which forwarded it to the tactical level where the other individuals of the Personnel Department were.

\subsection{The persuasion stage of the adopted technology}

It is in the persuasion phase that the individual deepens his knowledge about technology, seeking information about its advantages or disadvantages and attributes in order to develop a favorable or unfavorable attitude toward the same (Rogers, 1983, p. 165). When asked about the benefits and difficulties caused by the system adopted, the individuals cited many difficulties confronting more benefits.

Regarding the relative advantage (Rogers, 1983), the benefits cited by participants were: 1) speed, 2) ease of use, 3) greater integration between departments, 4) more accurate information, 6) adjustment to increase the volume of services. Thus, following a respondent's account of relative advantages of the new system:

"And the... the previous had this integration, but we do not... They had a degree of difficulty to make this very large integration and complexity also very large. In an integrated manner, but it had thus is he was specialized in one area and other areas had difficulties were suffered more 'right'. So in accounting, he was more specialized, but in the payroll area, personnel management area itself, in the financial area, he had more difficulty "(Interviewed DP - strategic)

Revista de Administração e Inovação, São Paulo, v. 13, n.1, p. 103-123, jan./mar. 2016. 
Referring to the complexity, Rogers $(1983$, p. 230) states that it is "the degree to which an innovation is perceived as relatively difficult to understand and use". So when the respondents were asked, individuals of the operational level who have direct contact with the system, they reported that, compared to other 'software', this provided greater ease of use and understanding. For Venkatesh, Thong and $\mathrm{Xu}$ (. 2012, p 6) the expectation effort is "the ease associated with the use of usertechnology"; Ease of use is a determining factor for the adoption whose meaning is "the degree to which individuals believe that using a particular system will be free of physical and mental effort." The subject ASDP2 (operating) confirms this evidence:

"(...) It is a good software because it's so simple, anyone who comes and 'gives' it a read in the handout can do:: then it is easy to deal with."

There are even greater ease of use compared to other market software, the subject DP (strategic) has listed as a difficulty to need high expertise and knowledge about the software. This may result from the fact that the same guy has informed that prior to adoption, the Department of Personnel did not have sufficient structure to perform more complex tasks. With the reabsorption of more complex tasks, it created the need to seek professionals that are more specialized.

Regarding testability (Rogers, 1983) from the ERP system, the DP interviewed of the strategic level claimed to looking for information from the partner organization that has provided the software license, holding meetings and visits to this organization. As well as the adoption had been positive, for the partner organization could be one for the organization under his command. However, it could not be applied to previous tests in the studied organization.

For Rogers (1983), the degree of testability of technology is positively linked to the adoption and the greater the degree of testability of a technology, the greater the propensity of the operative unit to adoption. However, the subject - the interpersonal communication channel - established between the studied organization and the partner organization, was convincing enough, driving adoption.

Regarding the observability (Rogers, 1983) of the results provided by the system, all subjects saw positive and tangible demonstrable, such as the reduction of days in minutes to perform certain tasks, as demonstrated by the CDP interviewed (tactical):

"(...) Today, it is already able to see, for example, things which would, for example, months, we can do today, for example, as in hours or even within minutes. Example: you take 600 accounts, to register in any system today; you do not spend less than five / six hours. Because of the complexity you have to go into screens, you have to register, inform, whenever you save the information in any system, it reassesses every other field to see if there's anything missing, there 'gives those inconsistencies'. Since the system came from another base, as "you" saved always lack something (laughs) he asks you

Revista de Administração e Inovação, São Paulo, v. 13, n.1, p. 103-123, jan./mar. 2016. 
to save. So we set up an accounts import mechanism, for example, we've spent here hours and hours to do that today, I do alone in five minutes."

An inherent aspect of the adopted technology, which is configured as a drawback, concerns the cost / price of the system. The respondent DP (strategic) reported that:

“(...) Well, the difficulty we had mainly refers to cost 'right', the financial cost of the software is not a cheap cost. Therefore, this cost, in a way, had a negative influence for us to take the decision."

The variable value / price is characterized in the literature as one of the determining factors of technology adoption (Tigre, 2006; Venkatesh, Thong \& Xu, 2012).

\subsection{The decision stage of the adopted technology}

After conducting a survey of benefits and difficulties arising from the adoption of the system in addition to their decisive characteristics for adoption, as stated in section 4.3 , the organization decided to adopt the technology. The decision stage is the one "in which the decision unit is engaged in activities that lead to choosing - to adopt or reject" (Rogers, 1983, p 172.). The account of the respondent DP (strategic) confirms the turning point:

"We looked at the number of benefits it could bring us the degree of difficulties and when we put on the scale, we find that the number of positives 'were' larger than the negatives. And then, just adopted."

Here again it verifies the importance of the factor Relative Advantage (Rogers, 1983) and also the relative value / price (Venkatesh, Thong $\& \mathrm{Xu}, 2012$ ) as factors often determinant for the process of adoption of technologies by organizations.

The two major reasons for the adoption of the software, observed the frequency of occurrence in the speech of respondents were "tool serves to increase the volume of services rendered" and "speed", precisely, which are the constructs that showed how the greatest perceived needs in section 4.1. Thus, Rogers (1983) reflects that, normally, when the perceived needs are met, there is a faster rate for the diffusion of innovation - logic that in this paper was applied to the adoption of technologies. 


\subsection{The implementation stage of the adopted technology}

The hiring IT professionals is often a necessary action so that the organization can implement a technology. The implementing stage "occurs when an individual (or other decision unit) puts the technology in use" (Rogers, 1983, p. 175). According to O'Brien (2004, p. 413), "the success or failure of an information service organization lies primarily in the ability of their staff." Another relevant factor refers to the training or time to practice using the system, defined by Aggelidis and Chatzoglou (2009) and Holden and Karsh (2009) as the realization of training programs on the use of IS before their introduction and during its operating period.

There was classroom and distance training involving only five members of the Personnel Department. However, these occurred after the introduction stage. The subjects had to apply the acquired knowledge directly to the practice, resulting in an adjustment phase and some mistakes in performing tasks. Some subjects evaluated the training as insufficient, resulting in the inability team to the system domain. The subject AA3 (operating) reveals this fact:

"(...) Since I've got, the first few months were a bit troubled, I didn't hit everything 'right', some things went wrong and had to be fixed, and:: it was only this, even a negative way it was this adaptation time, complicated."

It is important to note that in the cataloging of the literature made by Farias and Almeida (2014), self-efficacy, individual skills and training or practice time using the system are allocated as crucial variables in the implementation stage of a technology.

Another action taken refers to the "capacity planning" of the hardware structure, taken to Laudon and Laudon (2007, p. 123-124) as the process of analyzing and forecasting the saturation point of the hardware capacity. Thus, the CA1 interviewed (tactical) described the actions:

"Firstly, an analysis was made of the network, especially, the traffic information. Therefore, they (the subjects of the partner organization that gave the software license) evaluated the speed of the internet to see if she could attend. In fact, it works with remote access. Second, an analysis of the equipment that we have, computers and the adequacy of the hardware so the software could work perfectly."

While this was one of the actions carried out, it was a problem because the web did not involve the system, constantly getting out of breath. By opting up by adopting the new tool, the need for the transfer of the old software data to the database system used, which resulted in difficulties, since the information was not transferred perfectly, being in different standards and codes.

Revista de Administração e Inovação, São Paulo, v. 13, n.1, p. 103-123, jan./mar. 2016. 
New technologies bring with them changes on the way people are mobilized to work as well as important skills and behaviors to productivity. Linked to change is the resistance caused by: a) comfort in the status quo; b) disagreement about the reason for the change; c) doubt about the ability to achieve change (Graeml, 2000).

The enabling conditions are critical to the successful adoption of technologies. Some of these conditions are the existence of resources necessary for the adoption of the technology, the knowledge to use, compatibility with the technologies in use and the help of others when there is difficulty in using (Venkatesh, Thong \& Xu, 2012). If this is omitted by the decision maker of adoption process, it is possible that among several problems, there is an unfavorable attitude toward technology solution by the user.

Thus, the CDP interviewed (tactical) reports about the resistance to change:

\begin{abstract}
"(...) People always have that old story: 'I have always worked well," Someone came who wans to change, then this cultural issue is a bit complicated. Until people understand that it is the best, maybe not the best for you today, but tomorrow will be. We are aiming not only the question of now, but the question, in fact, the "institution", the "institution" will take the best, will earn more with regard to the corporate issue, that its employees may have a welfare better soon. Not so all this, the person, sometimes, understands and goes to the negative side that is the resistance. People sometimes have resistance to new technology and would not be different, for example, with TOTVS RM, as it 'moves' with all sectors ".
\end{abstract}

The implementation phase ends "when the new idea becomes institutionalized and part of the daily operations of the subject" (Rogers, 1983, p. 175). In the organization, it can be seen that this phase is ended, since the individuals of the tactical and operational levels reported dire need of using the system, by asking, "how it would work for them exercised without the use of the new 'software' which would be delayed, difficult, redoubled, and impossible. Only one subject reported that he would not change anything at his work, which demonstrates the stabilization of system use.

\title{
4.6 The confirmation stage of the adopted technology
}

As the confirmation step is taken as an evaluation of the positive and negative aspects of adoption in order to decide to continue the adoption or discontinue it (Rogers, 1983), in the following Table 2 is a summary of the presented needs by the organization related to the positive aspects of the decision process of technology adoption (columns 1 and 2 of Table 2), the negative aspects and

Revista de Administração e Inovação, São Paulo, v. 13, n.1, p. 103-123, jan./mar. 2016. 
problems faced (columns 3 and 4 of Table 2). Thus, one can undertake an analysis of the elements that underlie the organization during the confirmation phase (Table 2: Overall Rating Confirmation Stage).

Table 2: Overall Rating Confirmation Step

\begin{tabular}{|c|c|c|c|}
\hline \multicolumn{4}{|c|}{$\begin{array}{c}\text { Confrontation between the needs presented by the subjects to adopt the ERP system and } \\
\text { positives, negatives and problems faced checked in Step Confirmation }\end{array}$} \\
\hline Needs & $\begin{array}{l}\text { (2) Positive } \\
\text { Aspects }\end{array}$ & $\begin{array}{l}\text { (3) Negative } \\
\text { Aspects }\end{array}$ & $\begin{array}{l}\text { (4) Faced } \\
\text { Problems }\end{array}$ \\
\hline Control & Control & Value/Price & $\begin{array}{l}\text { Difficulty for data } \\
\text { transfer }\end{array}$ \\
\hline $\begin{array}{l}\text { Tool compatibility to } \\
\text { organization's needs }\end{array}$ & $\begin{array}{c}\text { There was research } \\
\text { and analysis of the } \\
\text { software }\end{array}$ & $\begin{array}{c}\text { Shortage of } \\
\text { professionals with } \\
\text { knowledge of the } \\
\text { software market }\end{array}$ & $\begin{array}{c}\text { Shortage of } \\
\text { professionals with } \\
\text { knowledge of the } \\
\text { software market }\end{array}$ \\
\hline $\begin{array}{l}\text { Information to support } \\
\text { decision }\end{array}$ & $\begin{array}{l}\text { Information to } \\
\text { support decision }\end{array}$ & $\begin{array}{l}\text { Implementation of only } \\
\text { a software module }\end{array}$ & $\begin{array}{l}\text { Growth in demand } \\
\text { for the services } \\
\text { offered by the } \\
\text { organization }\end{array}$ \\
\hline $\begin{array}{l}\text { Improve quality of } \\
\text { service }\end{array}$ & $\begin{array}{l}\text { Improved quality of } \\
\text { service }\end{array}$ & $\begin{array}{c}\text { Lack of training or time } \\
\text { to practice using the } \\
\text { system }\end{array}$ & $\begin{array}{l}\text { Infrastructure } \\
\text { disability }\end{array}$ \\
\hline $\begin{array}{l}\text { Administrative and } \\
\text { work }\end{array}$ & $\begin{array}{l}\text { Administrative and } \\
\text { work }\end{array}$ & Resistance to change & Resistance to change \\
\hline Agility & Agility & $\begin{array}{l}\text { Lack of staff capacity } \\
\text { on the system }\end{array}$ & $\begin{array}{l}\text { Lack of staff capacity } \\
\text { on the system }\end{array}$ \\
\hline System integration & System integration & - & - \\
\hline $\begin{array}{l}\text { Tool that meets the } \\
\text { increased volume of } \\
\text { services rendered }\end{array}$ & $\begin{array}{l}\text { Tool that meets the } \\
\text { increased volume of } \\
\text { services rendered }\end{array}$ & - & - \\
\hline automation & Facility to use & - & - \\
\hline \multicolumn{2}{|l|}{ Update } & \multirow{3}{*}{$\begin{array}{c}- \\
\text { Unknowledge } \\
\text { There was not } \\
\text { perceived negatives by } \\
\text { the subject }\end{array}$} & \multirow{3}{*}{$\begin{array}{c}\text { Unknowledge } \\
\text { There was not } \\
\text { perceived negatives } \\
\text { by the subject }\end{array}$} \\
\hline Unknowledge & Unknowledge & & \\
\hline & & & \\
\hline
\end{tabular}

Source: Empirical Research Evidences, 2015

By differentiating cells using the gray shading, it can see that many of the needs perceived in previous tools were met with the adoption of the new system. This led to a positive assessment by all those involved when asked about the intention to expand the use of the system for other departments, through the adoption of new modules to other areas of management. That is, there was not only an intention to further adoption but also the expansion tool because for those involved its provided benefits outweighed the negatives and problems faced. 


\subsection{On the search for possible innovations arising from the adoption of the studied technology}

This section examines whether there was generation of innovation from the adoption of the new system. When asked if the adoption of the system has brought improvements to the organization, the individuals cited various gains achieved, such as evidenced in subsections 4.1 to 4.6, this Section 4.

Considering the social perspective, the ERP system adopted enabled the expansion of the inclusion in the labor market in an educated way, of young people in vulnerable situations, and improve the quality of service offered to learners through the psychological care increase and assistance. The respondent CDP (tactical) reported that:

"(...) The social (gain), every job that is created is a tremendous benefit, socially, that when you take a young man and gives him a job, his father and mother have 'is' happy and, socially speaking, this young man is already included because it already has provided now buy some things, in a position to think about a better future."

The Brazilian government constantly monitors the partner-client companies of this organization in order to ensure compliance with the provisions of the Apprentice Law, adding the analysis of compliance with minimum quotas for hiring apprentices. Thus, inspectors have used reports provided by the organization for their analysis. The preparation of these reports has become easier and clearer and more reliable data following the adoption of ERP system studied. To obtain the exact data of the number of apprentices hired by certain company, agents can see which companies are actually complying with the mandatory minimum quota. Thus, there was administrative innovation (Birkinshaw, Hamel \& Mol, 2008 cited by Farias et al., 2011) in terms of improved accountability, so that the numbers generated in the reports have reflected more accurately the reality.

The improvement reported as "optimization" of process refers to the least effort caused by the reduction of manual tasks and increase of automated tasks that resulted in speed in performing the tasks. Participants addressed about the process improvement through agility:

"(...) Look, the great success we had with this software: what was done manually today is done in the form of files. So today, no one enters the bank's website to make payment of young, we just send the file and then released, authorize, and payment is made on the young man's account, the account of the person who works. The same is already happening with food stamps, everything is done on file so spent that time to manually type everything. Then so is:: brought many benefits and to optimize the time that we spent too much time on one thing, we started to not spend more this time. "(Interviewed CA1 - tactical)

Revista de Administração e Inovação, São Paulo, v. 13, n.1, p. 103-123, jan./mar. 2016. 
"(...) For example, we'll make one, post a payment, the other software would one by one, making launching one by one, in the current software we can now do all and just go changing what you have that change. :: And that's what 'okay' bringing better. "(Interviewed ASDP1 - operational)

Similarly, there have been improvements in the efficiency and processes as reported, respectively, by the subject DP (strategic):

"(...) If we had not adopted, as we win a bid, if we had not adopted this" site "whatever involved more than 1000 young people - then we would have no condition to make that management. Greatly improved the efficiency, we would have a much higher degree of difficulty if he had not used this new 'software"'.

Adopting the classification of the Oslo Manual (OECD, 2010), these changes can be classified as process innovations, considering that the increased operational efficiency with real gains exposed throughout this work were reported.

It has also improved administrative organization and work. So after the adoption of the technology, the sectors were structured. Laudon and Laudon (2007) state that by adopting an IT, it is necessary to make changes, among them structural and process. Thus the statement of the respondent $\mathrm{P}$ (tactical), following, enhances the evidence of a possible innovation in processes (OECD, 2010):

"(...) What I can gather a better definition ... of sectors, definition of each paper industry, greater wealth of information, exchange of information between sectors."

Therefore, the results of this research made it possible to check demonstrable results with the adoption of the system. Given this, it is inferred that there is evidence of the proliferation of administrative type Birkinshaw innovations; Hamel; Mol, 2008 cited by Farias et. al., 2011 and processes (OECD, 2010) of the adoption of the ERP system in the organization locus of the study.

\section{CONCLUSION}

This research aimed to describe, in view of the diffusion of innovations and technologies, the adoption process of an enterprise resource planning management system (ERP) in a non-profit organization, considering hindering factors and facilitators of this process and the possible innovations or gains. The presentation and discussion of the empirical evidence of qualitative approach - text corpus originating in the interviews - made possible the understanding that the positive factors 
outweighed factors that complicate and that some of the reported gains could be classified, based on literature, as administrative and processes innovations, through the implementation of new practices.

It was noted also that the adoption of the system took place in a context of change episodic nature, driven by external reasons (success in the bidding process to expand the range of services generated surge in demand for the services offered to the Jovem Aprendiz Brazilian Program) (Weick \& Quinn, 1999). From this event, the organization noted the need to improve and substantially expand its activities related to the program in order to support the new demand, and the new envisaged system like a technological solution able to meet the administrative needs of its Department of Personnel, through RM Labore module.

Finally, it is emphasized that Rogers (1983) proposes in its decision-making process, certain linear logic (well-defined stages of a diffusion process). However, respondents did not show lined perceptions faithfully the level of sequential reporting the process. This shows that the decision to adopt or reject certain technology solution or innovation presents diffuse and non-linear way. Thus, the intervening factors of adoption would not therefore present only in persuasion stage, but probably in the whole process (Farias \& Almeida, 2014). In addition, the non-linearity - the iterative - steps relating to these proceedings is discussed by Tornatzky and Fleischer (1990) and this may give rise to further discussion in future studies.

\section{REFERENCES}

Aggelidis, V. P.; Chatzoglou, P. D. 2009. using a modified technology acceptance model in hospitals. International Journal of Medical Informatics: 115-126.

Arthur, W. B. 2011. The nature of technology: what it is and how it evolves. New York: Free Press, 2011.

Cooper, R. 2000. Doing it right: winning at new products. Ivey Business Journal: 54-60.

Cooper, R. 1990. Stage-Gate Systems: a new tool for managing new products. Business Horizons: 4555.

Dias, D. S. 2000. Motivação e resistência ao uso da tecnologia da informação: um estudo entre gerentes. $R A C$, v.4, n.2, maio/ago. 
Mendonça, P.; Araújo, E. T. 2005. ONGs e Cooperação Internacional: entre a dependência e a busca pela sustentabilidade. Encontro da Associação Nacional de Pós-Graduação em Administração. Brasília: Anais do ENANPAD.

Farias, J. et. al. 2011. Adoção de prontuário eletrônico do paciente em hospitais universitários de Brasil e Espanha. A percepção de profissionais de saúde. RAP, Rio de Janeiro, 45(5): 1303-326.

Farias, J. S.; Guimarães, T. A.; Vargas, E. R. 2012. Innovation in Brazilian and Spanish hospitals: the managers' perception upon electronic patient record. BBR, Vitória, v. 9, n. 3, Art. 2, p. 23 - 44.

Farias, J.; Almeida, J. 2014. Technology adoption in service organizations: a framework proposal for studying ICT diffusion in healthcare and hospital services. XXIV International Conference of RESER. Helsinki.

Graeml, A. R. 2000. Sistemas de Informação: o alinhamento da estratégia de TI com a estratégia corporativa. São Paulo: Atlas.

Guion, L. A. 2002. Triangulation: establishing the validity of qualitative studies. University of Florida, FCS 6014.

Holden, R. J.; Karsh, B. T. 2009. A theoretical model of health information technology usage behaviour with implications for patient safety. Behaviour \& Information Technology 28, pp. 21-38.

Kelly, K. Para onde nos leva a tecnologia. 2012. São Paulo, Bookman.

Laudon K, K. C.; Laudon, J. P. 2007. Sistemas de Informação Gerenciais. 7. ed. $4^{\mathrm{a}}$ reimp. São Paulo: Pearson Prentice Hall.

Moura, B. C. 2006. Logística: conceitos e tendências. Lisboa: Centro Atlântico.

Motta, P. R. 2001. Transformação organizacional: a teoria e a prática de inovar. Rio de Janeiro: Qualitymark.

Mussi, F. B.; Canuto, K. C. 2008. Percepção dos Usuários sobre os Atributos de uma Inovação. Revista de Gestão USP, São Paulo, v. 15, n. especial, p. 17-30.

Organisation for economic co-operation and development (OECD). 2010. Oslo Manual, Measuring Innovation a New Perspective.

O’Brien, J. A. 2004. Sistemas de Informação e as Decisões Gerenciais na Era da Internet. 2. ed. $6^{\mathrm{a}}$ reimp. São Paulo: Saraiva.

Paulien C. et al. 2002. Multi-Method Triangulation in a Qualitative Study on Teachers' Practical Knowledge: An Attempt to Increase Internal Validity. Quality \& Quantity, n. 36: p. 145-167.

Rogers, E. M. 1983. Diffusion of Innovations. $3^{\text {rd }}$.New York: The Free Press.

Stal, E. 2007. Inovação Organizacional e Tecnológica. IN: Moreira, D. e Queiroz, A. (orgs.) Inovação Tecnológica, Sistemas Nacionais de Inovação e Estímulos Governamentais à Inovação. São Paulo: Thompson Learning, pp. 23-53. 
Tigre, P. B. 2006. Gestão da Inovação: a economia da tecnologia no Brasil. Rio de Janeiro: Elsevier.

Tornatzky, L. Fleischer, M. 1990. The process of Technology Innovation, Lexington, MA, Lexington Books.

Venkatesh, V.; Thong, J. Y. L.; Xu, X. 2012. Consumer Acceptance and Use of Information Technology: extending the unified theory of acceptance and use of technology. MIS Quarterly Vol. 36 No. 1 pp. 157-178/March.

Weick, K. E.; Quinn, R. E. 1999. Organizational Change and Development. Annual Review of Psychology, v. 50, p. $361-386$, Feb.

Zawislak, P. A. 1994. Relação entre Conhecimento e Desenvolvimento: a essência do progresso técnico. Textos Didáticos. DECON / UFRGS, Porto Alegre, November.

The date of receipt: 10/26/2015

The date of acceptance: 02/05/2016 